\title{
Victorian Literature and Modern China
}

\author{
Li Jing \\ School of Foreign Languages, Shanghai Maritime University, Shanghai, China \\ Email: leroyever@yahoo.com.cn
}

Received November $9^{\text {th }}$, 2012; revised December $9^{\text {th }}$, 2012; accepted December $15^{\text {th }}, 2012$

\begin{abstract}
In line with the Global Circulation Project, this paper addresses the meaning transformation of Victorian novel Yeast in modern Chinese context. Power relations under the reprocessing of Yeast are set out firstly. Literary openness of Yeast and the related heterogeneous parody are then discussed. Drawing support from reader response theory, the paper henceforth explores the discursive carnival of Yeast's hermeneutics. Finally the research anchors at the bay of a grand ethnographic setting where dwells critical responses on Yeast. Through discussions based on the novel, Chinese readers know themselves through alterity. The research suggests a relief map of the ecology of Victorian literature in a globalized context. The research finds its ethnographic root and textual preoccupation from a three year long fieldwork.
\end{abstract}

Keywords: Yeast; Chinese Readership; Victorian Culture; Globalization

\section{Introduction}

This essay aims at analyzing a group of modern Chinese readers' interpretations on the Victorian novel Yeast (1848). It is based on the ethnographic fieldwork done in six English classes in Hangzhou city, Zhejiang province, from 2009 to 2012. In this essay, the author intends to show the discursive relations between Victorian literature (culture) and specific discursive landscape in modern China in the context of post Victorian age. The readers' re-purposing of Yeast suggests the constructions of identity in terms of the poetic consumption of literature in the post-imperial epoch.

Like many other places in China, the site of this essay's fieldwork has been witnessing the subtle changes of culture in the process of modernization. Victorian age has been widely regarded as the Zeitgeist and threshold of modern society, the social mechanism of the Victorian age is showed through Victorian novels. Meanwhile, China is experiencing the similar step of the Victorian age, that is to say, the paradigm shifting from the agricultural culture to the industrial one. This case study suggests Chinese people's understanding on this change, reified through the media of Victorian novel reading. This small scale of qualitative study could be a necessary compliment of the macro social economic study of neo-Victorian study in terms of showing the heterogeneous processing of culture in the meaning travel of Yeast.

The moment has come to think about two interesting questions: why the novel Yeast (written by British writer Charles Kingsley in 1848) is introduced to the Chinese context? How would modern Chinese readers interpret Yeast? The answers could be put into a variety of ways, and each of them is part of the truism, but less than the whole of it. There is currently a lot of work in Victorian studies attempting to address questions of global ecology of Victorian literature (Gagnier, 2008; Gagnier \& Delveux, 2006), with the first complete edition of Dickens in Chinese forthcoming this year to coincide with the Dickens bicentenary celebrations and a "Global Circulation Project", supported by Literature Compass journal, which includes current and forthcoming publications on Dickens' works in China and Jane Eyre in eastern cultures. At the moment, this paper works along similar lines to these activities.

One way to approach the subject might be to begin by asking why China should be so fascinated with British nineteenthcentury works as opposed to, for instance, with British Renaissance drama and poetry or with the British eighteenth-century novel. Another might be to reflect on the extent to which present conceptions of "the Victorian" may in part be fantasy constructs based on idiosyncratic selective remembering of the past. After the Cultural Revolution (1966-1976), China has implemented the policy of reform and opening-up which fosters new cultural orientations in the national identity construction ${ }^{1}$. The nation has shifted from the political slogan of "based on class struggle" to the one of "based on socialist economic construction”. Hence all arts and humanity activities should serve the people and socialism (Hu Hui-Lin, 1999: p. 113).

One important aspect of such cultural political relocation is the study and consumption of foreign literature. A post-colonial imaginative national community ${ }^{2}$ is incubated by the discursive appropriation and transformation of foreign literary texts as well as the ideological implications thereof. Victorian literature has long been regarded as one important model in modern China's post-imperial national identity construction. What Raymond Williams sets out the realities of the English industrialization and urbanization ${ }^{3}$ in Victorian age are seen to be with significant historical resonance to China's modernization process. By studying the colonial Victorian past modern China is expected to be able to make a post-colonial national identity

\footnotetext{
${ }^{1}$ See Zhang Jing and Zhou San-Sheng. "Deng Xiaoping Theory and the Second Leap of China's Cultural Choice.” Journal of Graduate School of Chinese Academy of Social Sciences, Vol. 1, 2007: 15-22.

${ }^{2}$ About the post-modern concept of national identity see Benedict Anderson. “Imagined Communites.” London: Verso, 1983.

${ }^{3}$ See Raymond Williams. "The English Novel: From Dickens to Lawrence." London: Chatto \& Windus, 1970: 9-12.
} 
with potentially reactionary, even neo-imperialist writing ${ }^{4}$. These strategic cultural recycling and re-purposing altogether constitute a clear post-Victorian focus which supports and reinforces the meanings made by the dominant ideological discourses during the literary transfer process (Sherry 10).

In this context, academic research into Charles Kingsley (1819-1875) and his major works (Yeast, Alton Locke, The Water Babies) have been boarded the stage of Chinese history. Similar to China's preference to Dickens whose criticism on capitalism fits the ideological demand in China's socialist construction (Guo Ting, 2011: p. 798), Kingsley is regarded as "politically right" because of his Christian socialist identity ${ }^{5}$. Conceptualizations of Kingsley's works are repurposed and recycled which may in part be discursive constructs based on selective remembering of the past and its remaking of literary productions. Yin Qi-Ping, an established western literary critic

${ }^{4}$ The landscape of the imaginative construction on Victorian age in China since 1978 can be seen in the following works: Gao, Debu. "The Middle Department and Interim Employment in English Industrialization.” Journal of Southeast University (Philosophy and Social Science), Vol. 115.16, 2003: 44-47. Gao, Debu. "On Modern Times Economical Revolution of Great Britain.” Journal of Lanzhou Univ. (Social Sciences), Vol. 25.2, 1997: 26-32. "Urban Diseases of the Victorian Industrialization and its Primary Treatments." Academic Research, Vol. 1, 2001: 103-106. Han, Jianping. "Factor of the Conflict between British and Russia in Central Asia in Victorian Age.” Journal of Kashgar Teachers College, Vol. 29.4, 2008: 41-44. He, Liping. "On the Female British's Leisure Activities on the First Half of the Nineteenth Century.” Collection of Women's Studies, Vol. 13, 2005: 21-29. $\mathrm{Li}$, Xiaoxiang and Shu, Xiaoyun. "From Laissez-Faire to Approporiate Intervention: National Education Policies in the Industrial Revolution.” Journal of Xuehai, Vol. 1, 2005: 85-89. Qi, Yan. "The Typical Images of the Governess in the Vicotorian Novels-A Comparision between Jane Eyre and Rebecca Sharp.” Journal of Chengdu University (Social Sciences), Vol. 3, 2006: 59-66. Shi, Yihui. "The Ragged School Movement in Britain During the Victorian Age.” Journal of Huaiyin Teachers College (Social Sciences Edition), Vol. 1, 2005: 82-87. Shu, Xiaoyun. "An Analysis of the Family Types of the UK during the Idustrialization.” Social Science Journal of Qinghai Normal University, Vol. 12, 2000: 71-75. Song, Yanping. "The Conditions of British Working Class Women in Factories during the Industrial Revolution” Journal of Historical Science, Vol. 9, 2003: 95-100. Su, Aiping. "The Historical Position of the English Painting Schools in the Industrial Age.” Journal of Guizhou Normal University (Social Science), Vol. 1, 1999: 67-68. Sun, Dongbo. "The Government in the British Urbanization in the Victorian Age.” Journal of Yuncheng University, December 2005: 66-68. Tang, Maolin and Xiaohong Li. "Apprehend the Working Condition of Factory Workers during Industrial Revolution in Great Britain-Compare Marx's and Wren's Discussion.” Journal of Anhui Agricultural Sciences, Vol. 34.10, 2006: 2279-2280. Wang, Bei. "Cultural Factors of Victorian Surplus Women Population.” Jiang Huai Tribune, Vol. 15, 2005: 111-114. Wang, Jiu. "The Changing of Female Education in Victorian Age.” Journal of Zhejiang Normal University (Social Sciences), Vol. 1, 2002: 72-76. Wang, Rong. "The Representative of the New Female-A Brief Analysis of Sue Bridehead.” Shangdong Social Sciences, Vol. 11, 2006: 91-93. Yu, Yang. "On the Late Victorian Spectacular Theatre.” Foreign Literature, Vol. 1, 2008: 45-52. Zeng, Yaying. "The Prostitution Problem in British Cities in the Victorian Era." Collection of Women's Studies Vol. 3. 2005: 69-73. Zhang, Lina. "Feminine Consciousness in Feminine Fictions of Victoria Period in 19th England.” Journal of Shangqiu Teachers' College, Vol. 1123.111, 2007: 32-34. Zhao, Hong and Zhiyong Tian. "The Living Conditions of the Working Class in the British Industrialization." Journal of Beijing Normal University (Social Science Edition), Vol. 3, 2003: 34-39. Zhou, Wenying. "Methodism in England (1740-1840)." Journal of Jinan University (Phi- losophy \&Social Sciences Edition), Vol. 22.5, 2000: 78-83.

${ }^{5}$ About Christian Socialism and Kingsley's contribution to it see Brantlinger, Patrick. "The Spirit of Reform: British Literature and Politics, 1832-1867." Cambridge: Harvard University Press, 1977: 129-149. Brinton, Crane. "English Political Thought in the Nineteenth Century.” Cambridge: Harvard University Press, 1954. Cazamian, Louis. "The Social Novel in England 18301850: Dickens, Disraeli, Mrs. Gaskell, Kingsley.” Trans. Martin Fido. London: Routledge and Kegan Paul, 1973. and the forerunner of Kingsley criticism in China, constructs the notion of "alienated mechanism" as a nomenclature of the Victorian age many times ${ }^{6}$. Concerning with the theme of Yeast Yin argues:

The theme of Yeast is the quest for a spiritual homeland. Lancelot, the hero, goes through trials and tribulations in search of a spiritual anchorage in a fragmented world ... The world in which Lancelot lives is a society where the soul is lacking and which is bound to disintegrate in one way or another. It is apt and appropriate to represent Lancelot, together with his society, in a language whose style features “ruptures” and “fractures” (Yin Qiping, 2007: p. 185- 186).

Giving Yeast a Chinese socialist rhetoric of materialist dialectics while affirming the valid historicity by "simple styles based on linear narratives” (Clark, 1991: p. 45), Yeast becomes vivid (authentic), fluid (referential), time honored and timeless. Such incongruity is tolerated because history is by nature contingent and textual; exegeses are always welcomed and required. At the same time, however, a neo-Victorian perspective on the study of Yeast implies possibilities of a "critical paradigm precisely because it blurs the distinctions between criticism and creativity, with each becoming a reflection on self and other" (Llewellyn, 2008: p. 71). What Julliet John says about the "global Dickens" study also sheds light on a critical understanding of global Victorian study that "marks a return to scholarship as dialogue, dialogue that includes languages other than English, media other than books, and cultural institutions other than Universities”(John, 2012: p. 502).

Thus, this paper ventures to gaze at Yeast and its meaning travel in a critical ethnographic way, which has not been practiced in serious study in its own right. Seeing the novel's meaning travel as an ecological consumption process (Gagnier, 2008; Gagnier \& Delveux, 2006), I explore the cultural responses of the novel in the mass cultural context. From Jun 2009 to Jun 2012, as an innovative portion of my PhD dissertation $^{7}$, I introduce Yeast to 220 common Chinese people most of whom are college students or members of English nightclubs, a few groups of others are the parents or friends of these major contributors. The participants are invited to express their interpretations on Yeast by means of group discussion, insight paper writing, casual interview and passage translation. The culturally rooted interpretations and narrative strategies guarantee the revealing of primordial, profound and promising meanings rendered by the interpretations on Yeast. Such narrative style also shows a sharp anthropological sensitivity and meticulous wits in the life world. Hence, Yeast gives the Chinese a chance to see self through alterity. The following part of this paper shall discuss in a detailed way about Yeast's meaning travel in China.

\section{Openness of Yeast and the Chinese Responses}

Yeast is a bildungsroman firstly appears in Fraser's Maga-

${ }^{6}$ See "A Response to 'the Mechanical Age': A Tentative Approach to Alton Locke.” Foreign Literature Studies, Vol. 1, 2004: 61-65. “On Mackayep’s Death in Alton Locke." Foreign Literature, Vol. 4, 2007: 41-47. "The Artistic Form of Yeast." Journal of Zhejiang University (Humanities and Social Sciences), No. 5, 2007: 185-192.

${ }^{7}$ "Poetic Critique: A Study on Kingsley's Novels.” Zhejiang University and Copenhagen University, November 2011. 
zine in 1848 and is published finally in 1851. With a theme of regeneration and an attempt to show the "yeasty state of the young” (Kingsley, 1851, p. 266), the novel shows the Victorian reality through the looking glass. Historical and literary merits of the novel are echoed by many critics (Cazamian, 1973: p. 254; Beer, 1965: pp. 243-254; Scott, 1983: pp. 195-207; Kijinski, 1985: pp. 97-109; Derbyshire, 2006: pp. 58-64). At the same time, though Kingsley argues the fragmentary narrative of the novel is a way to show the "integral feature of the subject itself" (ibid), the fragmentary narrative has become a target of criticism. In particular, John C. Hawley comments Yeast as "glowing imagination, melodramatic incongruities" and thus "ill-ordered” (Hawley, 1991: p. 161). I shall show firstly how the fragmentary narrative could also be a symbol of the novel's openness, which provides a space for further interpretations.

\section{Lancelot's Monologue}

There is a typical fragmentary narrative appeared in the beginning of the novel: a monologue of the young bourgeois protagonist Lancelot:

Lancelot was now reading hard at physical science ... Bred up at home under his father, a rich merchant, he had gone to college with a large stock of general information, and a particular mania for dried plants, fossils, butterflies, and sketching, and some such creeds as this-That he was very clever.

That he ought to make his fortune.

That a great many things were very pleasant—beautiful things among the rest.

That it was a fine thing to be "superior", gentleman-like, generous, and courageous.

That a man ought to be religious. (Kingsley, 1851, pp. 12-13).

The five lines of monologue is what Stanzel (45) calls "figural narration"- a narrative genre that has a blending of firstperson and third person narration. "A third-person narrator recounts events filtered through the perspective or focalizing perceptions of a reflector figure", that is, a particularized center of consciousness (Herman, 2006: p. 208). In figural narration, it is not clear whether the statements are "authenticated by the narrator and which index the particularized, biased, thus nonauthoritative (or relatively less authoritative) cognitive-perceptual activity of a character" (ibid). The fuzzy boundary among these verbal representations is a mirror of the modernistic self-consciousness of people, or the inward turn.

In Lancelot's creeds, we sense the inward self realization of the hero and his historical presence. Such narrative style also reveals Kingsley's consciousness of a subtle age, which "marked a reactionary abandonment of the richly social worlds portrayed in nineteenth-century realistic novels, in the favor of the paralyzed self-awareness of the isolated consciousness" (ibid). The characteristic fragmentary narrative also reveals a rich range of heterogeneous dialogism in the fictional discourse, as Bakhtin states:

Thus at any given moment of its historical existence, language is heteroglot from top to bottom: it represents the co-existence of social-ideological contradictions between the present and the past, between differing epochs of the past, between tendencies, schools, circles and so forth, all given a bodily form. These "languages" of heteroglossia intersect each other in a variety of ways, forming new socially typifying "language” (Bakhtin, 1981: p. 291).

The double voiced meanings are reified in Lancelot's five creeds. The creeds are composed of five fragmentary sentences, each connected by the link word "that". These creeds are subjective motivation on the surface, for the narrator says they are Lancelot's creeds. However, here, the narration is used as one of the forms for concealing another's speech - the public discourse. If judged by the formal markers above, the logic motivating these five fragmentary sentences seem to belong to the character Lancelot. But in actual fact, the motivation lies within the subjective belief system of Lancelot, or of general discourse. The five link words "that" used to keep the logical sequence lose direct authorial intention. Rather they take on the flavor of the public discourse and thus become totally reified through the words "ought to". In this way the narration becomes an object of public discourse. Here the anonymous otherness hides in silence, yet it speaks powerfully. The parody of heteroglossia in the narrative implies Lancelot being a conscious self, whose consciousness however, is claimed by social discourse.

\section{Chinese Parodies against Lancelot's Monologue}

From an academic level, we can sense the irony implied in the passage whereas the majority of the participants in my fieldwork feel confused about the coherence of the passage, some of them even question the language ability of the author. Such kind of inaccessibility to Yeast's rhetoric application is also specified in the translation practice.

The following typical comments extracted from the fieldwork recording are a way to get access to the nuanced feedbacks against the literariness of Yeast. One participant says Lancelot is a college student who is very stupid, for the participant could not find the causal relation among these "that". Also some one says that she doesn't find anything tricky in the passage, but she thinks the passage is contradictory between the former part and the latter part, that is to say, in the former part Lancelot has a mania for physics but in the latter part he believes in religion. She concludes that those who take pains to learn physics must have a deep understanding in materialism, therefore he should not still believe in God.

Meanwhile some participants think the "that" looks weird. Someone says there is logical problems in the five "that", asking whether it is syllogism. Someone says that the passage is a bit too fragmentary and the rhythm is too fast, he only understands that Lancelot is a Christian. Someone says it is too hard to say anything. Someone says the passage is either written by philosophers or by the mentally disordered person, in a word, it is not written by common people. Someone says this passage is written when the author feels bored.

A girl says that how could "being intelligent and making fortune" have any ties with "creeds"-she could not understand the logic. To the whole novel this passage should be the most crucial part, however it is just this part that is not an elaborate one. The participant also says that she may also think about the passage in this way that from the language application's point of view, the key objective is to be articulate. This is a very important competence, yet hard to acquire. If someone does not have a solid language background, he would speak equivocally, therefore confuses others, just like what this passage does. 
I invite two groups of college students to translate the passage. One group is composed of 60 non English-majors, freshmen in college; the other one includes 90 English majors in college. It is an interesting fact to notice that though every one of the participants translates the meanings correctly, all of them actively omit the "that" in translation, therefore the ironic tone of these five creeds is weaken in Chinese versions. Also a key factor showing the cultural repurposing is on the diction in the translation of "religious". A lot of the participants used words that weaken the Christian orientation in the original text, instead they choose words such as “虔诚” (qiancheng, faithful), “真诚” (zhencheng, sincere), “谨慎” (jinshen, cautious), “有信 仰的” (youxinyangde, faithful).

Meanwhile several people consciously sense the irony in the passage. One participant says the information and creeds are very hypocritical. The creeds such as "making fortune", "very pleasant things among the rest" are practical and good. But these creeds such as "to be gentleman-like, to be religious" are too diplomatic and official. One participant reasons in a way that the creeds of being clever, making fortune, being religious and so on must not be modified by "ought to", for the propositional truth of these creeds are very situational indeed. One participant says "ought to" should be changed into "not always". She also says the author would not be a rich man so he is jealous of, or looks down upon Lancelot. And "a man ought to be religious" is a rebuke that Lancelot is actually not religious. One participant says "being clever" sometime means praise, sometimes could be an irony. The interpretation and translation on the monologue shows how local factors affect the understanding of Yeast.

\section{Carnival of Heteroglossia: The Four "Wh-" Discussions}

In this section an attempt to apply the reader reception approach to Yeast is achieved by the discussions on the four "wh-" questions based on Lancelot's monologue: Who is the protagonist Lancelot? Who is the author? When is the passage written? Why is the passage written? With a Husserlian "bracketing” of the actual context of Yeast, a thoroughly immanent understanding of the novel, without the influence of anything outside it, is expected. Yeast itself becomes the embodiment of Kingsley's consciousness, which show itself in the organic parts of a complicated totality. One is "concerned with the deep structures of this mind, which can be found in recurrent themes and patterns of imagery” (Eagleton, 1996: p. 51). The freewilled assumptions on the four "wh-" questions revealed a heterogeneous way of understanding Yeast.

\section{On "Who Is Lancelot?"}

Assumptions on Lancelot's identity are made according to the participants' direct grasp of the limited information provided by Lancelot's monologue. For many of the participants, moreover, their final conclusions rely on their knowledge in the life-world. It is worth noting that the cognitive path is largely made by a selective forgetting of all the other information in the monologue, which remains less sensitive or dormant in their knowledge storage. Thus the identity of Lancelot becomes very much situated. If one has to categorize those heterogeneous assumptions, the trajectory may be divided into the following parts.

Several participants focus on Lancelot's mania for plants and physical science, therefore Lancelot in their eyes is a scientist. Typical answers are: "Lancelot should be living in the era of Einstein, where there are many scientists"; "Lancelot will be the next Darwin"; "I think this paragraph is a part of a biography for Lancelot, and maybe Lancelot is a famous physicist now”.

Meanwhile many others pay attention on Lancelot's colorful hobbies and keen wit. Some of the participants say Lancelot could become a tomb robber ${ }^{8}$. Lancelot is also interpreted as "confident narcissist", "great but oversensitive", "hero in the idol drama”, "born in Renaissance”.

A majority of the participants are interested in Lancelot's family background: "bred up by his father, a rich merchant" (Kingsley, 1851, p. 12). Many of the participants show concerna on the cultural capitals of Lancelot guaranteed by his family status. Lancelot is imagined as "Jewish aristocrat", "the one live in the green house". Besides Lancelot is more frequently imagined as “富二代” (fuerdai, meaning one who is born with a silver spoon in mouth). The term “富二代” is a newly coinaged cultural symbol in mainland of china used in rather negative way pointing out the delinquent conducts of the privileged young as well as rebuking their remaining out of the law's reach. Therefore it is reasonable to see satirical tones in the comments on Lancelot's “富二代” identity. Also several participants say that the monologue mean to show the good points of these “富二代”.

There remain sporadic but also interesting assumptions on Lancelot. One girl concludes Lancelot is a knight of the Cart; the other girl says Lancelot lives in the middle age for his name should appear in that time.

\section{On "Who Is the Author?"}

A large member of the participants hold the author should be a "reporter", "magazine columnist", or "freelance” writing Lancelot's success, his biography or memoir.

Certain numbers of the participants say the author is a priest, a pastor or an idealist calling for the regeneration of religion and faithfulness in which his society lacks.

Many of the participants also say the author is Lancelot himself, because "many works are written according to the authors" own life experiences, for example, Jane Eyre. Lancelot is also imagined as "a young boy going to university", the reason is that "only students would have pure dreams". Some says that "under his father's great pressure, Lancelot uses the third person to narrate his current situation. His father is an idealist and hopes that his son can be as perfect as himself. But Lancelot does not want to do what his father wants him to do." Also many of the participants say the author is Lancelot's father or a senior citizen, who shows expectation to the young. Some say the author is an orphan looking forward to a rich businessman to be his father.

Some participants think the author may be Lancelot's friend, teacher, or current MA classmate, or "some girl having a unrequited love to Lancelot, so she asks Lancelot's roommate about his information. A few of the participants regard the author as a medieval English bourgeois who is particular about everything.

\footnotetext{
${ }^{8}$ Currently in mainland of China novels on robbing the ancient tomb are very popular. "Tomb robbing" novel is a newly invented one combining the genre of Chinese-style science fiction and martial arts novel. A lot of such novels are bestsellers among which the famous one is the serial of 《鬼吹 灯》 (guichuideng, Ghost Blows the Lamp).
} 


\section{On "When Is the Passage Written?"}

Many participants assume Lancelot's monologue is written in medieval age or just one remote time far distant from ours. Someone says "the literary style looks like medieval literature. The writer characterizes the protagonist as a decent, orthodox one." Someone says "at that time it was hard to earn money, it was the war time full of vulgarity and cruelty, and being very feudal, men were indoctrinated with creeds." Someone says "it was likely to be worked by the one who resisted papalism, and he wrote it to insinuate the dim papalism. It is very likely to be written in the late 6th century when the control of the pope over Italy reached its peak." Someone says the passage is written in a very ancient society, for the good manners at that time could hardly be see in modern China, the simplest example is when so many people are rushing on a bus.

Many of the participants focus on the humanistic, scientific and religious orientations implied in the passage, thus for them the passage is written in "Renaissance", "Platonic time", "Lincoln's time", "the early 20th century", "the industrial revolution", and "the Reformation" which are symbols of the spirits highlighted in the passage. Meanwhile a lot of participants are interested in Lancelot's class privilege, therefore the monologue is made "between the late 19th century and the early of the 20th century, when rich people learn something unpractical or anything they like such as arts and dry-plant collecting meanwhile common people would learn more practical things, such as law, medicine etc"; or in "colonist age”, "the early days of 20th century America” and so on.

There also appear typical assumptions that change their reasoning process, in which there exists no definite birth time of the monologue. One example is:

May be this passage was written is a small party, I feel it was in the late 19th century, may be in England, it was a time that people wanted to make fortune, respect knowledge, have the adventurous spirits and never stop perusing. Besides people at that time lacked no faith and nobleness. $\mathrm{Oh}$, it should be more possible that the passage was about America, and I think Lancelot is a Jewish. Oh no, it should be in England, in Europe. (Fieldwork transcription May 10th 2012).

The other example is:

This passage is definitely written by foreigners, those foreigners whose mother tongue is English. The hero's name is Lancelot; it is a name that should appear in middle age English. It used past tense; it seemed to be the genre of autobiography or memoir. The creeds such as making fortune, asceticism, to be religious and so on are the doctrines of the Protestants. Besides his father is a rich merchant, therefore the father should be in the late time of the middle ages. The hero is fond of fossils, sketches, which are the products of modern ages. Except the name "Lancelot," all the sentences and words in the passage are easy to understand, which shows that the author's writing time should at least be modern time after the Enlightenment. (Fieldwork transcription May 10th 2012).

\section{On "Why Is the Passage Written?”}

This last question is closely interrelated to the previous three ones. The totality of the four items of discussion creates a het- erogeneous discursive carnival where one finds a complex meaning transformation that establishes the ties between yesterday's Yeast and today's us. Coincidentally but also inevitably, most of the participants have keen wits to sense the theme of regeneration which is originally proposed by Charles Kingsley. Some participant relates a popular Chinese novel 《春宴》 (Chun Yan, Spring Feast) ${ }^{9}$ as a feedback on Lancelot's monologue: "Spring Feast also has a yearning for a regenerated life". The extraction of Spring Feast ${ }^{10}$ chosen by the participant implies intertextuality between Yeast and modern Chinese literature. The extraction of Spring Feast implies a discursive link between Victorian values and their modern Chinese variances:

Media worker Zhou Qing-Chang is doing a favor for her colleague - an interview. The interviewee is Xu Qing-Chi, a successful businessman. After the interview, Xu invites her to his house and takes in an evening feast. She goes to his house.

That is a typical middle class residence. Individual buildings bearing refined design locate elegantly in the spring garden. There are dawns open and flat, cherry trees and holy tress well pruned, swimming pools having green waves. Through the French windows, she can see the silk wallpaper in the dining room, crystal ceiling lamps, brocade sofas, wool carpets. Sculptures and handcrafts are on the tea table, on it there are English afternoon tea cups. In the garage there are SUVs and racing cars, children's bicycles and skateboards put randomly.

Life here represents itself as being affluent, stable, having enough leisure and easiness. However, this is an environment strange for Qing-Chang. This is not the class she is in. Yet she thinks this is the basic life form that a man ought to have. Shouldn't man live in a clean and aesthetic place? Shouldn't man enjoy leisure and rest? Shouldn't man, through his living life, keep a thorough balance between a dignified soul and his body? Impoverishment, wrestling, struggle, curse, dirtiness, ugliness, these things should not be in the formal life form. (My translation).

The illustration and analysis on the four "wh-" discussions show a trajectory of literary transmission of Yeast. The openness of Yeast guarantees discursive carnivals which reversely creates critical hermeneutical space. Meanwhile the next part of this paper focuses more on the reprocessing of Yeast in a broader textual sense.

${ }^{9}$ Spring Feast (2011) is a popular novel written by Anne Baby, discussing the young girls' contemplations on the relations between self and the environment, love and lost. The novel, due to its strong religious concern and publishing scrutiny process, postponed its publication.

${ }^{10}$ The original text is as follows: 媒体人周庆长出差, 帮她一名同事做一 个采访。对象是商业届的成功人士许清池, 见面简单采访后, 许清池邀 请她参加家中当晚的晚宴。她于是去到他家里。中产阶级典型住宅。建 筑优美排列和谐的独栋大厦, 分列在春日园林之中。平整开阔的草坡, 修剪得当的樱桃树和冬青, 游泳池水波碧蓝。透过落地玻璃窗, 可以看 见客厅丝织壁纸, 水晶吊灯, 织锦沙发, 羊毛地毯, 茶几上的雕塑和工 艺品, 英式下午茶白瓷杯碟。车库里有越野车, 跑车, 随意放置孩子们 的自行车和滑板。生活此刻呈现出富足, 安稳, 有余裕的自由和悠闲。 这种环境, 对庆长来说很陌生。这不是她所在的阶层。但她觉得这是人 应该拥有的基本生活形态。难道人不应该在清洁而又有审美的环境中生 存, 不应该享受到休闲和憩息的乐趣, 不应该在有生之年获得尊严、愉 悦、物质和精神同等丰足平衡的满足吗。赤贫、揪斗、咒骂、挣扎、污 脏, 丑婳。这不是常态。

(http://book.kanunu.org/files/chinese/201108/3394/31778.htm accessed on August 2nd 2012). 


\section{Relief Map of Alterity: Stories of Education, Nation and Us}

Finally the meaning travel anchors at the bay of a grand ethnographic setting where dwells critical responses on Yeast. Discussions on education, nation and the selves revived by readings on Yeast are showed and analyzed. In light of this perspective, one should perhaps be more impressed by the regenerative interpretations on Yeast, which dramatically echoes the novel's very theme: regeneration. A lot of college students are inspired by Lancelot's growth; many of them want to be another regenerated Lancelot. Some of them say no matter who Lancelot's God is, in modern China, the so-called God is just yourself:

Era: You live in the society. Survival of the fittest. You could only be washed out if you are not good enough.

Zheng: We have to face the reality.

Zhang: No one can escape from the society. (Fieldwork transcription June 9th 2009).

Meanwhile a group of English nightclub members show critical concern about their own country after finishing reading Yeast. Dora (a 26 years old foreign trade company secretary), Spring (a 40 year old pharmacist) and me discuss the fleeing of faith in modern China:

Dora: Foreigners usually hold religious beliefs, and some of them think that

Teacher: Let's discuss it. You don't think the Chinese hold religious beliefs, right?

Dora: The Chinese have got very, very superficial comprehension on religion.

Teacher: For instance?

Spring: Recently some people have not held enough beliefs.

Dora: Their beliefs are mostly superstitious. The foreign religious beliefs require people to do good deeds and to think in some way. Anyway, they work in this way.

Spring: It is related to their culture.

Teacher: Then what we have learnt, take the Confucius thinking which teaches you how to live and behave, for instance. Don't you think it is

Dora: Um, what I said about religious beliefs is ... (pause). Not mention Confucius. We don't usually tag Confucius as our religious belief or something we should embrace. (Fieldwork transcription April 8th 2009).

Jason (a 46 year old computer company manager) praises the five creeds showed in Lancelot's monologue as a "positive encouragement". This approval can also be seen in many participants' insight papers, which, ironically, runs counter to Yeast's plot development. Jason also thinks the "earnest attitude" that Lancelot's society has are buried in his nation due to mammonism:

Jason: Yes, it is a positive encouragement, which cultivates an affirmation of one's own importance. One should be confident and be a person of value. Under the influence of it, one believes that one is gentle. It is good to be gentle. To be generous is good, as well as to be brave. All the above are virtues. One should pursue these virtues. But the present core value is mammonism here.

Teacher: Take for instance, “a man ought to be religious”.
How do you think about religious?

Dora: This kind of belief demonstrates that one should hold the faith, which does not mean believing something. In other words, faith is one's thinking and one's attitude to the world. No matter it is right or wrong, the faith is what one believes. If one insists and doesn't give it up, the result will be different. But faith is important in one's heart, especially when one uses it to do something.

Teacher: Why do you think Chinese have a superficial comprehension of religious beliefs?

Spring: What are the religious beliefs you mentioned?

Dora: In my opinion, for example, the Chinese don't attach too much importance to religious beliefs. The old lady with two pistols ${ }^{11}$, for instance.

Jason: Briefly speaking, it is an earnest attitude. What we lack is the earnest attitude, toward everything.

Dora: It depends. What you said is too superficial.

Jason: It is a common phenomenon in China. You cannot

find such a bad thing even in the worst country in the world. (Fieldwork transcription April 15th 2009).

The nuanced and subtle integration of time and space encourage us to think about what Amanda Anderson holds as the fundamental cultural roots that shape today's history (Anderson, 2005). Such a perspective offers a "critical paradigm precisely because it blurs the distinctions between criticism and creativity, with each becoming a reflection on self and other" (Llewellyn, 2008: p. 71). Victorianist Valerie Sanders argues that films and literature are significant agents that foster contemporary students' attitudes towards Victorian age (Sanders, 2007). Such idea finds its clear evidence from the data sources of this paper. What's more I would argue that one could not ignore the power of receptive context. It is worth noting that the appropriation and transformation of Victorian texts, motifs across time and between cultures, as well as the ideological implications thereof construct new meanings of Victorian culture in a post-Victorian globe.

\section{Conclusion}

Given the limited space available, this paper ventures to address the relief map of Yeast's meaning travel in a critical way. Localized transformation of Yeast shows the ecology of Victorian literature and its yeasty regeneration in modern China. Yeast in this sense is not simply a novel, but "a text, a commodity, a discourse, and a piece of international cultural capital” (Jordan, 2009: p. 6).

This paper implies alternative dimension of future Victorian study. To make Victorian literature and culture authentic and intelligible in an alien society, one would have to start by asking how the local receptors see their experience being retransformed and reconstructed in order to add meanings to their experience and increase their ability to direct future experience. In this way, the meaning travel of Yeast could be identified as a heritage process, for as the pioneer of heritage study Laurajane Smith says, the idea of heritage is gazed "as an act of communication and meaning making ... indeed as an experience ... not so much as a "thing", but as a cultural and social process, which engages with acts of remembering that work to create ways to

\footnotetext{
11“The old lady with two pistols” (“双枪老太婆”, shuangqianglaotaipo) is a legendary narrative on an old woman fighting the Japanese invaders with excellent shooting skill during the Sino-Japan war (1937-1945). This narrative has frequently been adopted and reprocessed on Chinese screen.
} 
understand and engage with the present (Smith 2).

\section{Acknowledgements}

This project is supported by Science \& Technology Program of Shanghai Maritime University.

\section{REFERENCES}

Anderson, A. (2005). Victorian studies and the two modernities. Victorian Studies, 47, 195-203.

Bakhtin, M. M. (1981). The dialogic imagination. Four Essays. Austin: University of Texas Press.

Beer, G. (1965). Charles Kingsley and the literary image of the countryside. Victorian Studies, 43-54.

Cazamian, L. (1973). The social novel in England 1830-1850. London and Boston: Routledge \& Kegan Paul.

Clark, P. (1991). Two hundred flowers on China's screens. In C. Berry (Ed.), Perspective on Chinese cinema (pp. 40-61). London: BFI Publishing.

Eagleton, T. (1996). Literary theory: An introduction. Minneapolis: University of Minnesota Press.

Foucault, M. (1998). On the ways of writing history. Robert Hurley and others, Translated. Aesthetics, Method and Epistemology. The Essential Works of Michel Foucault 1954-1984. Harmondsworth: Allen Lane, Penguin, 284.

Gagnier, R. (2008). Literary alternatives to rational choice: Historical psychology and semi-detached marriages. English Literature in Transition, 51, 23-43.

Gagnier, R., \& Delveaux, M. (2006). Towards a global ecology of the Fin de Siècle. Literature Compass, 3, 572-587. doi:10.1111/j.1741-4113.2006.00333.x

Guo, T. Dickens on chinese screen. Literature Compass, 8, 795-810.

Hawley, J. C. (1989). The water-babies as catechetical paradigm. Children's Literature Association Quarterly, 14, 19-21.
Herman, D. (2007). Dialogue in a discourse context: Scenes of talk inn fictional narrative. In B. Michael (Ed.), Narrative-state of the art (p. 208). Philadelphia, PA: John Benjamins Publishing Company.

Hu, H.-L. (1999). On the paradigm shifting and reconstruction of modern China's cultural policies. Journal of Shanghai JiaoTong University (Social Science), 7, 110-115.

John, J. (2012). Global Dickens: A response to John Jordan. Literature Compass, 9, 502-507. doi:10.1111/j.1741-4113.2012.00895.x

Jordan, J. O. (2009). Global Dickens. Literature Compass, 6, 1211 1223. doi:10.1111/j.1741-4113.2009.00664.x

Kijinski, J. L. (1985).Charles Kingsley's yeast: Brotherhood and the condition of England. Victorian Institute Journal, 97-109.

Kingsley, C. (1851). Yeast: A problem. London: Parker.

Llewellyn, M. (2008). What is Neo-Victorian studies? Neo-Victorian Studies, 1, 164-185.

Maynard, M., \& Purvis, J. (1994). Researching women's loves from a feminist perspective. London: Taylor \& Frances.

Murfin, R., \& Ray, S. (1998). The bedford glossary of critical and literary terms. St Martins: Bedford Books.

Sanders, V. (2007). Where next in victorian literary studies? Historicism, collaboration and digital editing. Literature Compass, 4, 12921302.

Scott, P. (1983) Charles Kingsley. In I. B. Nadel, \& W. E. Fredeman (Eds.), Victorian novelists before 1885. Dictionary of Literary Biography (pp. 195-207). Detroit: Gale Research.

Sherry, S. (2010). Censorship in translation in the Soviet Union: The manipulative rewriting of howard fast's novel. The Passion of Sacco and Vanzetti, Slavonica, 16, 1-14

Simpson, G. (1982). Origins and growth of sociological theory. Chicago, IL: Nelson-Hall.

Smith, L. (2006). Uses of heritage. New York: Routledge.

Stanzel, F. K. (1984). A theory of narrative. Goedsche, G., Translated. Cambridge: Cambridge University Press.

Yin, Q. P. (2007).The artistic form of Yeast. Journal of Zhejiang University (Humanity and Social Sciences), 37, 186-192. 